\title{
The Effect of School Head Managerial Capability and Learning Facilities on Performance Teacher Department of Tourism Vocational School in Manado City
}

\author{
Virginia H Saneba Henny N Tambingon Mozes M Wullur \\ Magister Education Management Postgraduate Program \\ Manado State University, Indonesia
}

\begin{abstract}
Absract
This research aimed to describe and analyze: 1) the effect of principal's managerial ability toward teacher tourism performance at vocational high school in Manado City, 2) the effect of learning facilities toward teacher tourism performance at vocational high school in Manado City, and 3) the effect of principal's managerial ability, and learning facilities simultaneously toward teacher tourism performance at vocational high school in Manado City. Survey method was implemented with qualitative approach. Population unit were 97 teacher of tourism major at Vocational High School in Manado City. Research sample were 49 teachers which randomly selected from 97. Questionnaire with Likert scale was the technique used to collect the data. Testing the hypothesis using simple and multiple correlation analysis. The result of data analysis showed that: 1) there was effect of principal's managerial ability toward teacher tourism performance at vocational high school in Manado City, $22,7 \%$. 2) there was effect of learning facilities toward teacher tourism performance at vocational high school in Manado City, 51,6\%. and 3) there was effect principal's managerial ability, and learning facilities simultaneously toward teacher tourism performance at vocational high school in Manado City, 51,6\%. Based on these conclusion, it could be recommended that: 1) Principal's managerial competencies to be improved so that a professional school managerial system can be formed, 2) the availability of learning facilities is more adequate, so that it raises efficiency in the learning process, 3) The regional education department is expected to be able to synergize with the school in an effort to improve the principal managerial competencies, such as in terms of education and training, improvement of academic qualifications, and assistance with learning facilities.
\end{abstract}

Keywords: Teacher Performance, Managerial Abilities, Learning Facilities, ,

DOI: $10.7176 / \mathrm{JEP} / 10-11-07$

Publication date: April $30^{\text {th }} 2019$

\section{Introduction}

The current global development and information era spurred the Indonesian people to further improve the quality of human resources, because quality human resources are the main capital in development in all fields. With high quality resources, the Indonesian nation is expected to compete with other more advanced nations. . As we know, education is essentially a process of interaction between educators and students that aims to develop quality human resources. This requires efforts to implement quality education in all types and levels. Priority efforts to improve the quality of education are basically focused on three main factors, namely the quality and amount of educational resources to support the teaching and learning process, the quality of teaching and learning processes in the context of implementing curriculum and learning, and the quality of educational output, in terms of knowledge, attitudes and the skills of the students.

The improvement of quality education needs to be regulated in a national policy. Therefore, efforts to improve the quality of education have become the government's full attention. The relationship with this requires the teacher's role to produce quality resources. For teachers to play a role, there needs to be an effort to improve the quality of teachers, especially in the learning process. In other words, so that the learning process is of high quality, the teachers must also be qualified and professional. In line with the statement above, Usman (2002: 45) states that "Professional teachers are people who have special abilities and expertise in the field of teacher training, so that they are able to perform their duties and functions as teachers with maximum abilities". The important teacher role gives an idea of the quality of school graduates. Imron (2015: 58) argues that "the quality level of teachers is seen as the cause of the level of quality of school output." Therefore, the teaching profession needs to be continually developed so that it can perform its functions professionally.

In general, good quality education is a benchmark for the performance shown by the teacher. In principle the teacher has a high enough potential to be creative in order to improve his performance. However, this potential does not always develop naturally and smoothly because of the influence of various factors, both those that arise from within the teacher itself and from outside the teacher's personal. It cannot be denied that conditions in the field often reflect the state of the teacher who is not in line with expectations. There are still many teachers who have not been able to initiate, create, and innovate in implementing learning. Besides that there are still teachers who lack discipline, often late, there are even teachers who do not make preparations so 
the learning process does not run smoothly and the results are not in line with expectations. This fact is very concerning and invites various questions about the consistency of the teacher to his profession.

On the other hand, the teacher's performance was questioned when discussing the problem of improving the quality of education. The controversy between the ideal conditions that must be lived by the teacher and the reality that occurs in the field is something that is necessary and should be examined in depth about the factors causing the problem. Therefore, the factors that influence teacher performance are deemed necessary to be studied, studied and studied in depth so as to provide a clear picture of more important and urgent factors that affect teacher performance. Mulyasa (2012: 49) states that, "what is meant by learning facilities is equipment and equipment that is directly used and supports the educational process", especially the teaching and learning process, such as buildings, classrooms, desk chairs, as well as tools and teaching media. The definition of education infrastructure is a facility that indirectly supports the course of the education or teaching process, such as yards, gardens, parks, roads to schooling, but if used directly for teaching and learning processes, such as school parks for biology teaching, school pages as as well as sports fields, these components are educational facilities.

It is clear that teacher performance can develop if the principal is able to carry out his managerial functions and adequate learning facilities. These factors affect the performance of the teachers. The tourism department teachers in vocational high schools (SMK) in the city of Manado were not free from the problems of teacher performance. In general the state of the teacher shows good performance. But behind that there is still a lack of readiness of the teacher in the learning process. Besides that, it also deals with discipline in the teaching and learning process, namely teachers who tend to be less creative in teaching so that it creates boredom in learning. Learning facilities that tend to be inadequate so that the quality of graduates tends to be less reliable. Another thing that is also a concern is the managerial ability of the principal who tends not to be innovative and sensitive to existing situations and conditions. Certainly the problems mentioned above are expected to be an effort to minimize them so that they become better.

Based on the research of researchers at the Manado City Tourism Office that the absorption of graduates of Vocational School students in Manado City every year shows an improving trend which means that it is accepted in companies involved in the world of tourism. This can be seen from the last 3 years that in 2015 vocational graduates were absorbed as much as $11 \%, 2016$ as much as $18 \%$ and in 2017 as much as $23 \%$ (2018 data on the sub-department of staffing, general and law of the Manado City Tourism Office).

In this research design is devoted to measuring the extent of the role of teachers involved in tourism majors at SMK in Manado City. The presence of Vocational Schools in Manado City is spread in 36 schools with the details that there are 8 state Vocational Schools and 28 private Vocational Schools. all of the Vocational Schools with majors / expertise in the field of tourism are only spread in 13 Vocational Schools (4 Public Vocational Schools and 9 Private Vocational Schools). As for the scope of the tourism majors are expertise in the field of business travel, hospitality and hotel accommodation. analysis and interpretation of: Effect of principals' managerial competencies on the performance of teachers in tourism majors at Vocational High Schools in the city of Manado. Effect of learning facilities on the performance of tourism vocational school teachers in the city of Manado. Effect of managerial competency of principals and learning facilities together on the performance of tourism vocational school teachers in the city of Manado

\section{Literature review}

\subsection{Teacher Performance.}

Definition of performance comes from the word job performance / actual performance. So performance can be interpreted as an achievement that appears as a form of work success in a person. According to the Big Indonesian Dictionary (Balai Pustaka, 2016: 570), performance means "something is achieved; achievements shown; work ability (tt equipment). "Whereas according to Stoner, James, A, F, and Edward Freeman (in Wahyudi, 2012: 86)," Performance is the quantity and quality of work completed by individuals, groups or organizations. "Furthermore, according Mangkunegara (in Wahyudi, 2012: 86), performance is the result of work in quality and quantity achieved by an employee / teacher in carrying out his duties in accordance with the responsibilities given to him. This performance concerns three components, namely quantity, quality and effectiveness, all three of which cannot be separated from one another. Performance can also be interpreted as a result and effort of someone who is achieved by the existence and ability in certain situations.

The teacher's performance is the result achieved by the teacher in carrying out the tasks assigned to him based on skills, experience, and seriousness and use of time. Teacher performance is a tangible result of quality and quantity achieved by a teacher in carrying out his duties in accordance with the responsibilities given to him which includes compiling learning programs, implementing learning, and evaluation analysis. The measure of the teacher's performance can be seen from his sense of responsibility in carrying out his duties, mandate, his profession, and a sense of moral responsibility on his shoulders. All of that will be seen in compliance and loyalty in carrying out their professional duties in school and outside the classroom. This attitude is in line with 
the sense of responsibility in preparing all learning equipment before carrying out the learning process. In addition, in preparing the implementation plan, the teacher must prepare and consider the methods, techniques, or strategies that will be carried out in delivering the material. In conducting the evaluation, the teacher must also prepare the assessment technique that he will do.

Hariani quoted by Indrawijaya (2013: 91) states that there are a number of teacher / teaching staff performance in carrying out the teaching and learning process, which are popular among such models including Ron Norris Model, Oregon model and Stanford model. All three are known as Stanford Teacher of Appraisal Comperence (STAC), briefly he three models are:

1. Rob Norris's model.In this Model there are several teaching components that need to be possessed by a teaching staff / teacher, namely (a) personnel qualities and formulation of teaching objectives (b) teaching preparation (c) formulation of teaching objectives (d) teacher's appearance in teaching in class (e ) teacher's appearance in learning and (f) evaluation.

2. Oregon model. According to this model teaching ability is grouped into five parts (a) planning and preparation for learning, (b) teacher's ability to teach and students' ability to learn, (c) ability to collect and use information on learning outcomes, (d) interpersonal relationship skills that include relationships with students, supervisors and peer teachers, and (e) relationship skills with professional responsibility. 3. Stanford model.This model divides teaching abilities in five components, three of the five components can be observed in the class including the objective component, the teaching component of the teacher and the evaluation component. Factors that affect Teacher Performance.

A person's performance does not arise by itself, but is influenced by several factors. According to Mitchell (in Wahyudi, 2012: 89), the factors that influence performance are as follows: 1. Quality of work.Good quality work shows that a person has a good performance. Conversely, if the quality of the work is bad then the performance is weak. 2. Accuracy. Someone who can work properly in accordance with the instructions that should be and is supported by someone's speed at work, indicating that someone has a good performance. Someone who has good performance, is able to work properly, quickly and neatly. 3. Initiative. Someone who has high performance has good initiative in carrying out every task and responsibility charged to him. He utilizes the potential of his mind to always find new creativity that can improve his work, have ideas, new findings. 4. Capability. A good level of work is observed from capability. Someone who has good ability will be able to solve all the problems that arise in his job well and happy to accept many challenges. 5. Communication. A person who is of a high level, can communicate well, both with superiors, subordinates and with colleagues. If everything is communicated well then the conditions faced can be resolved well too.

\subsection{Managerial Ability.}

The term ability is the meaning or meaning of the word competency, which comes from English 'competence' which means: "1) skill, ability; 2) authority (Echols and Shadily; in Mustafa, 2016: 10). Understanding of competence according to Thoha (2014: 19) is "the ability to carry out or do a job or task based on skills, and the knowledge and support of work attitudes demanded by the job". While in Kepmendiknas 045 / U / 2002 (Lasut, 2008: 29) defines "competence as a set of intelligent and responsible actions that a person has as a condition to be considered capable by the community in carrying out tasks according to a particular job". Then according to the Directorate of Staffing the Director General of Higher Education of the Ministry of Education concluded that basically "competence is the roundness of mastery of knowledge, skills, and attitudes displayed through performance, which is expected to be achieved by someone after completing an education program" (Lasut, 2008: 29). Furthermore Wahyudi (2012: 28), states that "competence means skills, abilities and authority. A person is declared competent in a particular field if he masters work skills as an expertise in harmony with his field. "Understanding (2015: 25) defines" competence as the ability to carry out something obtained through education and training. Competence is obtained through education and training with certain standards and qualities in accordance with the task to be carried out ".

As stated by Supandi (Wahyudi, 2012: 28) that: "Competence is a set of abilities to carry out a position, and not merely knowledge. Competence requires cognitive abilities, affective conditions, values, and certain specific and specific skills related to the characteristics of the position or task carried out. Specific capabilities are intended so that the principal can carry out the task properly and with quality. The principal who fulfills the criteria and requirements for a position means authority over the position or assignment given in other words fulfilling the competency requirements.

Managers according to Stoner (Wahyudi, 2012: 67), are "people who use resources to achieve goals". The opinion that is almost the same is stated by Handoko (2014: 15) that, "managers are people who have responsibility for subordinates and organizational resources". Principals in managing educational units are required to master certain competency skills that can support the implementation of their duties.

In the Minister of National Education Regulation No. 13 of 2007 dated April 17, 2007 concerning the Standard of Principals / Madrasas concerning the special qualifications of the Principal said that the Head of a 
High School School is, among other things, "status as a high school teacher" (Zainal Aqib, 2012: 141). are teacher functional staff who have an additional task to lead and manage one of the school assignments in which the education and learning process is held. Leadership and management of educational institutions effectively and efficiently, a principal must certainly have various competencies. Competence is generally interpreted as skills, skills, and abilities. According to Wahjosumidjo (2014: 4): "the description of the duties and responsibilities of the principal can be seen from two functions, namely the principal as an administrator and as a supervisor." Principal as administrator at school has duties and responsibilities for all managerial processes that include planning, organizing, mobilizing, and overseeing all fields of cultivation which are the responsibility of the school. The management field can cover personnel, students, administration, curriculum, finance, facilities and infrastructure, school and community relations and other supporting units; whereas, the principal as supervisor is related to service activities to increase the professionalism of teachers in order to achieve a quality learning process. From a number of opinions and concepts compiled by the principal's managerial abilities are the skills and knowledge of a school principal in managing organizational resources effectively and efficiently in order to achieve predetermined goals. The indicators are as follows; 1). Planning, 2). organizing, 3). drive, and 4). Supervision

\subsection{Learning Facilities}

Understanding of learning facilities, can present some limitations from experts. According to Zakiah Daradjat "facilities are all things that can facilitate efforts and facilitate work in order to achieve a goal. Whereas according to Suryo Subroto "facilities are everything that can facilitate and facilitate the implementation of a business in the form of objects or money. More broadly about the notion of failitas Suhaisimi Arikonto argues, "facilities can be interpreted as everything that can facilitate and facilitate the implementation of all things business. As for those who can facilitate and carry out this business, they can be in the form of objects or money, so in this case the facilities can be equated with the facilities available at the school. From several opinions formulated by experts regarding the definition of facilities, it can be formulated that facilities in the world of education mean anything physical or material, which can facilitate the implementation of teaching and learning processes, for example with the availability of classroom learning equipment, teaching aids, textbooks, libraries, various equipment for laboratory practice and everything that supports the implementation of the teaching and learning process.

As for what is meant by learning according to Wasty Soemanto, is "the basic process of the development of human life, by learning human beings carry out individual qualitative changes so that their behavior develops". While according to Slameto learning is "a business process carried out by individuals to obtain a change in new behavior as a whole, as a result of the experience of the individual himself who interacts with his environment". From the definitions of learning put forward by the experts above, it can be concluded that learning is an activity carried out intentionally to obtain a good change in the form of experience. Behavior and skill. The definition of learning facilities is all the needs needed by students in order to facilitate, facilitate and support learning activities in schools. In order to be more effective and efficient, later learners can learn to the maximum and satisfying learning outcomes. Facilities and infrastructure are supporting elements in the implementation of tut wuri handayani, which includes buildings, furniture, equipment (hardware and software), and systems for securing assets and schools. In accordance with its vision, mission or mandate, a vocational school requires the development of a management system that includes planning, procurement, data collection, utilization, maintenance, deletion, and updating all facilities and infrastructure.

Vocational secondary schools must have specific guidelines regarding the completeness and adequacy of the facilities and infrastructure needed, including the classification system, inventory and information on their existence. Vocational secondary schools must have a management system that guarantees wider access, especially for students and teachers through the application of resource models sharing. Other forms of ownership such as leases, loans or grants must be stated in a letter of agreement between the school and the parties related to clear legal certainty. Mulyasa (2012: 49) states that, "what is meant by learning facilities is equipment and equipment that is directly used and supports the educational process", especially the teaching and learning process, such as buildings, classrooms, desk chairs, as well as tools and teaching media . The definition of education infrastructure is a facility that indirectly supports the course of the education or teaching process, such as yards, gardens, parks, roads to schooling, but if used directly for teaching and learning processes, such as school parks for biology teaching, school pages as as well as sports fields, these components are educational facilities. b. Learning Facilities Standards.

The standard of facilities and infrastructure, education aims to guarantee the quality of education so that graduates can compete in the global era. This standard will function as a national baseline for all interested parties, in three terms, namely (1) planning and designing facilities and infrastructure; (2) implementation of procurement and maintenance of facilities, and infrastructure; and (3) monitoring the availability and condition of facilities and infrastructure. 
Academic infrastructure is the main supporting device for an educational process or effort so that educational goals are achieved. Means are anything that can be used as a tool / media in achieving the purpose or purpose. Academic infrastructure can be divided into 2 (two) groups, namely: a) Building infrastructure, including land and building for both the purposes of lecture rooms, office spaces, lecture rooms, seminar rooms, meeting rooms, laboratory rooms, studio rooms, library rooms, computer rooms, experimental gardens, workshops, public facilities and welfare, such as hospitals, student service centers, sports and arts infrastructure and student dormitories.b) Public infrastructure in the form of water, sanitation, drainage, electricity, telecommunications networks, transportation, parking and parks (National Accreditation Board for Higher Education, 2017).

Facilities of Learning and infrastructure to support the improvement of education for all academicians in a college more specifically on the faculty. Understanding the media leads to something that delivers / transmits information (message) between the source (the giver of the message) and the recipient of the message. Media is all forms and channels that can be used in an information presentation process (AECT Task Force), in Latuheru, 2009: 11). Robert Heinich et al (2008: 6) suggested the definition of the medium "as something that carries information between the source (source) and receiver (receiver) information". Mulyasa (2012: 49) states that, what is meant by learning facilities are equipment and equipment that are directly used and support the educational process, especially the teaching and learning process, such as buildings, classrooms, desk chairs, and tools and media for teaching.

The meaning of learning infrastructure is a facility that indirectly supports the course of the education or teaching process, such as a yard, a garden, a school park, a road to school, but if used directly for teaching and learning processes, such as school parks for biology teaching, school yard as well as sports fields, these components are educational facilities. The main characteristic of learning activities is the existence of interactions. Interactions that occur between the learning and the learning environment, both with teachers, friends, tutors, learning media, and or other learning resources. Where in learning there will be components as follows; objectives, teaching material / materials, methods and media, evaluation, students / students, and the presence of educators / teachers (Riyana, 2017. "Learning Components". www.kurtek.upi.ac.id 2018/10). Learning tools are equipment and equipment that are directly used and support the educational process, especially the teaching and learning process, such as buildings, classrooms, desk chairs, as well as tools and teaching media. The meaning of education infrastructure is a facility that indirectly supports the course of the education or teaching process, such as yards, gardens, school parks, roads to schools, but if used directly for teaching and learning processes, such as school parks for biology teaching, school yard as well as sports fields, these components are educational facilities.

The research hypotheses are:

1. There is the influence of the principal's managerial abilities on teacher performance.

2. There are effects of learning facilities on teacher performance.

3. There is an influence of the principal's managerial ability and learning facilities together on teacher performance

\section{Research Method}

This study uses a quantitative approach, a survey method with correlational techniques. This study will examine or analyze the dependent variable; teacher performance and independent variables; 1) principal managerial ability (X1), and 2) learning facilities (X2). The research model is illustrated in the figure below.

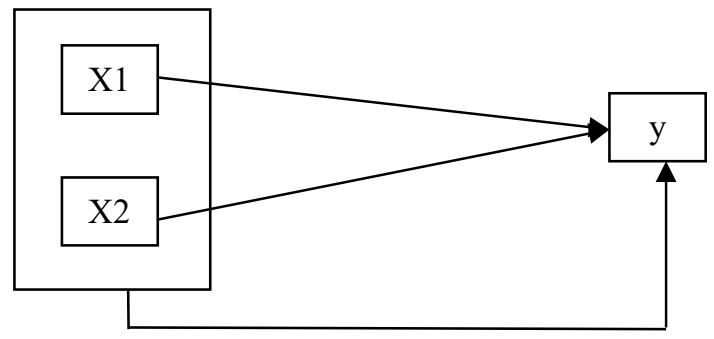

Place and time of research : This research was carried out on the teachers of the vocational high school tourism department in Manado city for more than four months from November 2018 to March 2019. Before the data collection several preparatory activities related to the research included; preparation of theoretical frameworks, preparation of research instruments and instrument trials. Population is an object / subject that has certain qualities and characteristics specified in this study. In this study the population units are teachers in the tourism department of Vocational High School in the city of Manado. The sample was calculated based on the Taro Yamane formula and obtained as many as 49 respondents. 
Data collection has been carried out with a direct survey of all Tourism Vocational Schools in Manado. The data collection tool used is a questionnaire or questionnaire. Preparation of the questionnaire through planning with the following steps: 1) identify the measurement objectives, namely about the variables to be measured, the sample to be measured, see the distribution of items, and determination of the characteristics of respondents, 2) see the contents of the measuring instrument in accordance with which will measure the meaning of measuring instruments must contain items from the whole, the part to be measured, and whether it is suitable with the dimensions to be measured, and 3) see and identify items in accordance with theoretical conceptions.

Before explaining the data analysis used to test the research hypothesis, first it will explain the influence between research variables. This influence will clarify the data analysis used in testing the hypothesis. Data analysis used descriptive analysis, correlation and multiple regression. Before testing the hypothesis, analysis requirements were tested which included the normality test of the data with the Liliefors test while the significance and linearity tests used the regression equation. Using probabilistic sampling techniques, which provide equal opportunity for each element (member) of the population to be selected as a sample member. In determining the sample size, a formula developed by Issac and Michael was used, with error rates of $1 \%, 5 \%$ and 10\% (Sugiyono, 2016: 126 - 128), to determine the sample size based on a 5\% error tolerance level.

\section{Result and Discussion}

4.1.Effect of the principal's managerial ability on teacher performance.

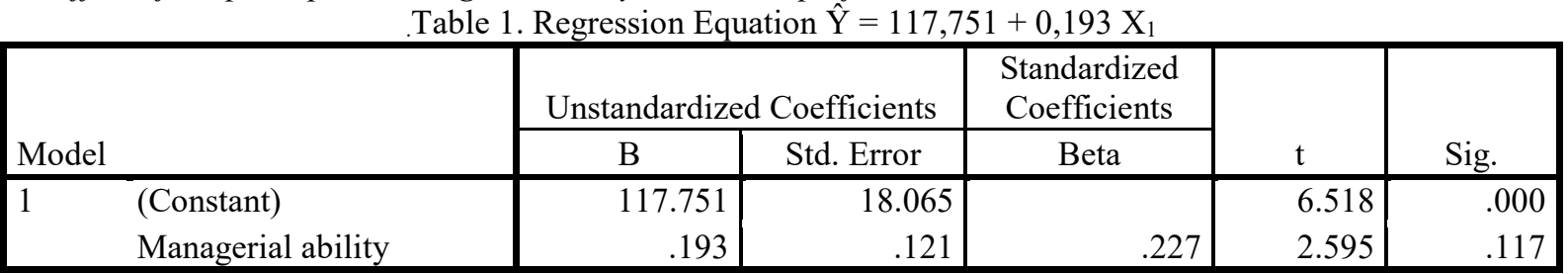

a. Dependent Variable: Teacher performance

The calculation results produce a regression equation $\hat{\mathrm{Y}}=117.7510 .193 \mathrm{X} 1$ with a correlation coefficient $(\mathrm{r})$ $=0.227$ with $\mathrm{r} 2=0.51$. Next in testing hypothesis 1 with a real level of $\alpha=0.05$ and $\mathrm{dk}=\mathrm{n}-2=49-2=47$, the value of $t(0.05 ; 47)$ table $=2.01$; The calculation results get a value of tcount $=2$. Based on these criteria it turns out that the value of tcount $=6.52>$ the value of $t$ table $=2.01$ so that $\mathrm{H} 0$ is rejected. So it can be concluded that: Principal's managerial ability has a significant influence positively influencing the performance of vocational high school teachers in the city of Manado.

Based on linear regression analysis $\hat{\mathrm{Y}}=117.751+0.193 \mathrm{X} 1$ it can be explained that the regression coefficient of the principal managerial ability variable is a positive value, which is 0.051 ; it means that whenever there is an increase in managerial capacity of the principal, the teacher's performance will increase with a score of 0.051 . This means that the more increasing managerial ability of the principal (X_1), the higher the teacher's performance $(\mathrm{Y})$, or in other words that the principal's managerial ability has a significant influence on the performance of vocational high school teachers in the city of Manado.

Because based on the results of this study that managerial ability of principals is one of the contributing factors in order to improve and improve teacher performance, it can be argued that the implications of this research are to improve and improve teacher performance, it is necessary to improve the poor ways of a school leader. This is in accordance with the opinion of some experts, among others: Mulyono (2008: 144) explains "the role of school principals is needed to manage human beings in school organizations, including having the right strategy to manage conflict. The principal must be in place the forefront and its success can be measured ".

Leadership and management of educational institutions effectively and efficiently, a principal must certainly have various competencies. Competence is generally interpreted as skills, skills, and abilities. According to Wahjosumidjo (2014: 4) "the description of the duties and responsibilities of the principal can be seen from two functions, namely the principal as an administrator and as a supervisor." The principal as an administrator in the school has duties and responsibilities for all managerial processes that include planning, organizing, mobilizing, and supervising all fields of work which are the responsibility of the school. The management field can cover personnel, students, administration, curriculum, finance, facilities and infrastructure, school and community relations and other supporting units; whereas, the principal as supervisor is related to service activities to increase the professionalism of teachers in order to achieve a quality learning process. 


\subsection{Effect of learning facilities on teacher performance.}

Table 2. Regression Equation $\hat{\mathrm{Y}}=68,969+0,612 \mathrm{X}_{2}$

\begin{tabular}{|c|c|c|c|c|c|}
\hline \multirow[b]{2}{*}{ Model } & \multicolumn{2}{|c|}{ Unstandardized Coefficients } & \multirow{2}{*}{$\frac{\text { Standardized Coefficients }}{\text { Beta }}$} & \multirow[b]{2}{*}{$\mathrm{t}$} & \multirow[b]{2}{*}{ Sig. } \\
\hline & $\mathrm{B}$ & Std. Error & & & \\
\hline 1 (Constant) & 68.969 & 18.824 & & 3.664 & .001 \\
\hline Learning Facility & .612 & .148 & .51 & 4.133 & .000 \\
\hline
\end{tabular}

a. Dependent Variable: Teacher performance

The calculation results produce a regression equation $\hat{Y}=68,969+0,612 \mathrm{X} 2$ with a correlation correlation coefficient $(\mathrm{r})=0,516$ with $\mathrm{r} 2=0,267$. Next based on the above testing table at a real level $\alpha=0.05$ and $\mathrm{dk}=\mathrm{n}-2$ $=49-2=47$, the value of $\mathrm{t}(0.05 ; 68)$ table $=2.01$; The calculation results get the value of tcount $=3.67$. Based on these criteria it turns out that the value of tcount $=3.67>$ the value of $t$ tabell $=2.01$ so that $\mathrm{H} 0$ is rejected. So it can be concluded that:Learning facilities have a significant influence positively influencing the performance of vocational high school teachers in the city of Manado.

Based on linear regression analysis $\hat{Y}=68,969+0,612 \mathrm{X} 2$ it can be explained that the regression coefficient value of the learning facility variable is positive, which is 0.267 ; it means that whenever there is an increase in learning facilities, the teacher's performance will increase by increasing the score to 0.267 . This means that the more fulfilled learning facilities $\left(\mathrm{x}^{\wedge} 2\right)$, the higher the teacher's performance $(\mathrm{Y})$, or in other words that learning facilities have a significant influence on the performance of vocational high school teachers in the city of Manado.

Because based on the results of this study that learning facilities are one of the contributing factors in order to improve and improve teacher performance, it can be argued that the implications of this research are to improve and improve teacher performance, it is necessary to add and improve the quality of learning facilities and infrastructure in schools. This is in accordance with the opinion of some experts, among others: Mulyasa (2012: 49) states that, "what is meant by learning facilities are equipment and equipment that are directly used and support the educational process", especially the teaching and learning process, such as buildings, classrooms , desk chairs, as well as tools and teaching media.

The definition of education infrastructure is a facility that indirectly supports the course of the education or teaching process, such as yard, mini hotel, tourism cars, gardens, parks, roads to schooling, but if used directly for teaching and learning processes, such as parks schools for biology teaching, school yard as well as sports fields, these components are educational facilities. In this study learning facilities were identical to educational facilities. Government Regulation Number 19 of 2005 concerning National Education Standards, Chapter VII Standards for Facilities and Infrastructure, article 42 confirms that: 1). Every education unit must have facilities that include furniture, educational equipment, educational media, books and other learning resources, consumables, and other equipment needed to support a regular and continuous learning process, 2). Each education unit must have infrastructure that includes land, classrooms, education unit leadership rooms, educator rooms, administrative rooms, library spaces, laboratory rooms, workshops, production units, canteen rooms, power installations and services, sports venues, place of worship, place of play, place of creation, and other space / place needed to support a regular and continuous learning process

4.3 The influence of the principal's managerial abilities and learning facilities together on teacher performance.

Table 3. Calculation of Coefficients Y for X1 and X2

\begin{tabular}{|l|r|r|r|r|r|}
\hline \multirow{2}{*}{ Model } & \multicolumn{2}{|c|}{ Unstandardized Coefficients } & Standardized Coefficients & \multirow{2}{*}{ Sig. } \\
\cline { 2 - 5 } & \multicolumn{1}{|c|}{$\mathrm{B}$} & Std. Error & Beta & 3.242 & .002 \\
1 (Constant) & 68.058 & 20.990 & .014 & .103 & .919 \\
& .012 & .118 & .510 & 3.675 & .001 \\
\hline
\end{tabular}

a. Dependent Variable: Teacher performance

Based on the results of data processing as listed in table 3 the research hypothesis testing was obtained $\hat{\mathrm{Y}}=$ $68,058+0,012 \mathrm{X} 1+0,605 \mathrm{X} 2$. Based on the testing table, it is obtained $\mathrm{p}(\mathrm{y}, 12=0.267$. With a real level of $\alpha=$ 0.05 and $\mathrm{dk}=(\mathrm{k} ; \mathrm{nk}-1)=(2 ; 49-2-1)=(2 ; 46)$ obtained $\mathrm{F}$ value $(0,05 ;(2 ; 46))$ table $=3.19$; The calculation results get a value of Fcount $=8.37$. Based on these criteria it turns out that the value of Fcount $=8.37>\mathrm{F}$ value $(0.05 ;(2 ; 46))$ table $=3.19$ so that $\mathrm{H} 0$ is rejected and accepts $\mathrm{H} 1$. Principal managerial abilities and learning facilities together have a positive effect on the performance of vocational high school teachers in the city of Manado.

Based on linear regression analysis $\hat{\mathrm{Y}}=68,058+0,012 \mathrm{X} 1+0,605 \mathrm{X} 2$ it can be explained that the regression coefficient value of the learning facilities variable is positive, which is 0,267 ; it means that every time there is an increase in the managerial capacity of the principal and learning facilities together, the teacher's 
performance will increase by increasing the score to 0.267 . This means that the more increasing managerial abilities of principals and the fulfillment of learning facilities (X_1), the higher teacher performance (Y), or in other words that principals' managerial abilities and learning facilities together have a significant influence on the performance of secondary school teachers vocational in the city of Manado.

Because based on the results of this study that the managerial abilities of principals and learning facilities are contributing factors in order to improve and improve teacher performance, it can be argued that the implications of this study are to improve and improve teacher performance, it is necessary to change and improve efforts from principals in terms of managerial abilities and improving the quality of learning facilities and infrastructure in schools. This is in accordance with the opinion of several experts, among others: According to Indrawijaya (2013: 83) teacher performance consists of teacher performance in designing the teaching and learning process and teacher performance in carrying out the teaching and learning process. One of the stages of teaching that must be passed by professional teachers is to arrange teaching plans or in other words also called "designing teaching programs". Teaching or instructional design planning helps teachers direct the steps and activities and performance that will be displayed in the teaching and learning process in achieving goals.

There are several teacher performance indicators as outlined in the main tasks and functions of the teacher as follows: The teacher is responsible to the Principal with the main task of carrying out learning activities effectively and efficiently. Therefore, it needs to be supported and equipped with learning facilities in the form of adequate and quality facilities and infrastructures. As stated by Mulyasa (2012: 49) that, learning facilities are equipment and equipment that are directly used and support the educational process, especially the teaching and learning process, such as buildings, classrooms, desk chairs, wifi, leptop and, LCD and devices. other teaching tools and media0. As well as learning infrastructure are facilities that indirectly support the course of the education or teaching process, such as yards, gardens, school parks, roads to schools, but if used directly for teaching and learning processes, such as school parks for biology teaching, school yard as well as the field sports, these components are educational facilities.

\section{Conclussion}

Based on the results of the research and discussion, in response to the formulation of the problem and research objectives, the conclusions of this study are as follows:

1. The managerial ability of principals has a significant influence on the performance of vocational high school teachers in the city of Manado. This means that the managerial ability of the principal will encourage and move the teacher to be proactive and positive about the work situation will provide satisfaction in carrying out the duties and responsibilities so that the teacher's performance will increase.

2. Learning facilities have a significant influence on the performance of vocational high school teachers in the city of Manado. This means that good and quality learning facilities make teacher performance will increase.

3. Principal managerial abilities and learning facilities together have an influence on the performance of vocational high school teachers in the city of Manado. This means that the increased managerial ability of school principals and the availability of available learning facilities will have implications for the increase in the performance of vocational secondary school teachers in the city of Manado

\section{References}

Buchari Alma, H, et al. 2009. Professional Teachers, Mastering Methods and Teaching Skills, Alfabeta, Bandung.

Chaplin,J.P.1997. Complete Dictionary of Psychology Translator Kartini Kartono. Raja Grafindo Persada.Jakarta

Kewo, C. L., \& Afiah, N. N. (2017). Does Quality of Financial Statement Affected by Internal Control System and Internal Audit?. International Journal of Economics and Financial Issues, 7(2), 568-573.

Davis Gordon. 1991. Basic Framework of Management Information Systems. Section 1 PT. Reader Binamas Pressindo. Jakarta.

Djamal, Z. 2005. Certification and License of Professional Lecturer. Journal of education, Bandung:

Gibson, James L.1994.Organization Behavior,Structure and Process, (Nunuk Ardiani Translation, Bina Aksara, Jakarta).

Gultom, Shawwal. 2013, School of Target Curriculum 2013. EPIK, Jakarta.

Handayaningrat, Soewarno, 1988, Pengatar Science Study Administration and Management, CV. Hajimas Agung, Jakarta.

Handoko, T. Hani. 2001. Personnel and Human Resource Management, Second Edition.

BPFE, Yogyakarta 2003, Relationship Situational Leadership and Motivation. BPFE, Yogyakarta

Hasibuan, M.S.P. (2000). Human Resource Management. Bumi Aksara, Jakarta (2005).

Human Resource Management. (Revised Edition), Bumi Aksara, Jakarta (2007),

Hunt, Gilbert H. 1999. Professional Teacher Performance Master's Perception Relationship on Leadership Head, 
Gramedia, Jakarta

Kepmenpan No. 25 / Kep / M.Pan/4/2002, on Guidelines for the Development of State Apparatus Culture Work

Kemendikti-Unima, 2011. Teacher Professionalism: Teacher Profession Training Material, Rayon 27 Unima, Tondano

Madjid, A, E. 2008, Learning Planning, Developing Teachers Competency Stadards. PT Remaja Rosdakarya, Bandung

Mahsun, Mohamad, 2006. Public Sector Performance Measurement, first print, BPFE. Yogyakarta

Mangkunegara A.A. Anwar Prabu. 2002. Human Resource Management Company, PT Remaja Rosdakarya, Bandung

Makmur, H., 2007. Pathology and Therapy in the Science of Administration and Organization, Relika Aditama, Bandung

Mantur Jan F, 2010. the influence of Organizational Climate Leadership Style and Job Satisfaction of Teacher Performance at State Senior High School in Manado. Dissertation,. PPS Program UNJ, Jakarta

Martinis Yamin, H. 2013. Teacher Professional \& KTSP Implementation, Reference / GP Pres Group, Jakarta

Pranoto, June, H., \& Adam Ibrahim Indrawijaya H, 2011. Strategy of Public Administration and Management Update, Alfabeta, Bandung

Purwanto, 2010. Evaluation of Learning Outcomes, Pustaka Belajar, Yogyakarta,

Rawis, Joulanda A.M. 2016. Supervivi Klinis, Reference Book, LP2AI - Unima, Tondano

Reigeluth, Charles M \& Robert J. Garfinkle, 1994, Systemic change in Education, Educational Technology Publications Englewood Cliffs, New Jersey

Robert R. Katz, in Moenir. 2008. Public Service Management in Indonesia Bumi Aksara, Jakarta:

Robbins, S., and Timothy A. J. 2008. Perilakudan Organization Management (Translation), Gramedia, Jakarta

Sagala, Syaiful H, 2009. Contemporary Education Administration, Alfabeta, Bandung

Sahertian, P, 2000.Basic Concepts and Technical Supervision of Education, National Business, Surabaya

Sadili, Samsudin. 2005. Human Resource Management, Pustaka Setia, Bandung

Santosa, Pandji, 2009. Public Administration: Theory and Application of Good Governance, Refika Aditama, Bandung.

Saroni Mohammad, 2011. Personal Branding Master: Improving the Quality and Professionalism of Master, Ar.Ruzz Media, Yogyakarta

Sedarmayanti, 2007. Human Resource Management, Bureaucratic Reform and Civil Servant Management: PT. Refika Aditama, Bandung

Simamora, Henry, 2000. Human Resource Management, STIE YKPN, Yogyakarta,

Slameto. 2010. Learning and Factors Affecting it, Rineka Cipta.Jakarta

Sudjana, Nana, 1983. Assessment of Teaching and Learning Process Results, PT Remaja Rosdakarya, Bandung

Sudjana, Nana. 2000. The Basics of Teaching and Learning, Tarsito, Bandung

Sugiyono, 2007 \& 2009. Educational Research Methods (Quantitative Approach, Qualitative and R \& B), Alfabeta, Bandung.

Tambingon, Henny N., 2011, Relationship of Self-efficacy, Job Satisfaction, and Emotional Intelligence with Working Commitment of High School Teacher of State Manado.

Tambingon, Henny N.2012. Principal Leadership Style, Bayu Media Publishing, Malang

The Liang Gie, 1980. Modern Office Administration. 10th Print Publisher Nur Cahaya, Yogyakarta.

Umar, Husein, 2004. Research Method of Administration Science, PT. Gramedia Pustaka Utama, Jakarta.

Law of the Republic of Indonesia Number 20 Year 2003, on National Education System.Diknas.Jakarta.

Law of the Republic of Indonesia Number 14 Year 2005, concerning Teachers and Lecturers

Wahyudi Imam, 2012. Pendidiklan Development, Achievement, Jakarta

Winardi, J. 2007. Motivation and Motivation in Management. Jakarta 